\title{
НАСЕЛЕНИЕ ЗАПАДНОЙ СИБИРИ В ГОДЫ ВТОРОЙ МИРОВОЙ ВОЙНЫ: 1939 - 1945 гг.*
}

\author{
ВЛАДИМИР ИСУПОВ ${ }^{1, * *}$, НАДЕЖДА КОРОБЕЙНИКОВА ${ }^{1}$, МИХАИЛ СЕМЕНОВ $^{1}$
}

\begin{abstract}
В статье рассматриваются особенности демографических прочессов в Западной Сибири во время Великой Отечественной войны. К ним относятся резкие изменения численности и структуры населения, обусловленные мобилизацией в армию и развернувшимися в годы войны миграционными прочессами, прежде всего эвакуачией. Основныли детерминантами пространственных перемещений людей в этот период стали военно-политические факторы. Государственный контроль над территориальныли перемещениями людей был резко усилен. За время войны резко сократилась численность сельского населения, но количество горожан за счет притока мигрантов возросло, в результате чего выросла доля городского населения региона, произошла его квазиурбанизация. Вследствие изменений структуры населения и общего ухудиения условий жизни значительно снизилась рождаемость, что стало главной причиной естественной убыли населения в 1942-1944 г2. Смертность же, после повышения в первые годы войны, с 1943 г. стала снижаться, общий коэффициент смертности в 1945 г. был более чем вдвое ниже, чем в 1941. Важнейшую роль в этом снижении сыграла система здравоохранения.
\end{abstract}

Ключевые слова: численность населения, половозрастной состав, смертность, рождаемость, брачность, Западная Сибирь, Вторая мировая война.

\section{ВВЕДЕНИЕ}

Совокупность демографических знаний о таком периоде российской истории, как годы Второй мировой войны, позволяет выявить основные тенденции развития общества в контексте социальной, ментальной, политической и экономической турбулентности, ставшей характерной чертой этого непростого этапа. Однако в масштабах огромной страны, которая в военные годы включала в себя и оккупированные территории, и регионы, ставшие театром военных действий, и тыловые районы, усреднение базовых показателей приводит к методологическим искажениям и заставляет исследователя углубляться в изучение региональной специфики, о чем свидетельствует выход в свет большого количества работ, посвященных развитию народонаселения в 1940-е годы. Западносибирский регион стал уникальным примером демографической динамики в тыловых районах в условиях острого кризиса общества, превратившись в импровизированную экспериментальную площадку выживания как для местных жителей, так и для многочисленных эвакуантов и беженцев. В контексте данной проблематики особую остроту приобретают такие вопросы, как общие показатели естественного движения населения, а также его ключевые факторы.

\footnotetext{
${ }^{1}$ ИНСТИТУТ ИСТОРИИ СИБИРСКОГО ОТДЕЛЕНИЯ РОССИЙСКОЙ АКАДЕМИИ НАУК (РОССИЯ).

* СТАТЬЯ ПУБЛИКУЕТСЯ В РАМКАХ ПРОЕКТА РГНФ «ЛЮДСКОЙ ПОТЕНЦИАЛ СИБИРИ В УСЛОВИЯХ СИСТЕМНОЙ ТРАНСФОРМАЦИИ РОССИЙСКОГО ОБЩЕСТВА В ХХ ВЕКЕ», № 16-01-00412.

** E-mail: vladimir_2004_@mail.ru

СТАТЬЯ ПОСТУПИЛА В РЕДАКЦИЮ В ФЕВРАЛЕ 2016 Г.
} 
К сожалению, в рамках одной статьи трудно осветить все проблемное поле развития населения в Западной Сибири в военные годы, поэтому нами были выделены основные вопросы, такие как воспроизводство населения, а также такие специфические процессы, во многом определявшие эти показатели, но в годы войны подвергшиеся значительным искажениям, как брачно-семейные отношения и развитие здравоохранения в контексте борьбы за нормализацию эпидемиологического фона.

В настоящей статье наше внимание сосредоточено на Западной Сибири, в динамике населения которой в концентрированном виде нашли отражение все основные тенденции демографической истории России в 1939-1945 гг. Это регион, который стал одной из главных строительных площадок первых пятилеток и в то же время служил местом заключения для многих тысяч людей. Перед началом Второй мировой войны в состав Западной Сибири включались Алтайский край, Новосибирская и Омская области (по административно-территориальному устройству 1939 г.). Таким образом, регион вбирал в себя типично сельскохозяйственные районы (Алтайский край, юг Новосибирской и Омской областей) в сочетании с индустриально развитым, высоко урбанизированным Кузбассом (территория современной Кемеровской области, выделившейся из состава Новосибирской области в 1943 г.).

\section{ВОСПРОИЗВОДСТВЕННЫЕ ПРОЦЕССЫ В 1939 - ПЕРВОЙ ПОЛОВИНЕ $1941 \Gamma$.}

Во Вторую мировую войну население Западной Сибири вступало с положительным приростом населения. Данные, представленные в таблице 1, показывают, что за период с 17 января 1939 г. по 1 января 1941 г. численность населения региона выросла в абсолютном выражении почти на 340 тыс. человек, превысив в конце 1939 - начале 1940 г. девятимиллионный рубеж. Темпы роста численности населения региона в 1939-1941 гг., по сравнению с предшествующим периодом, несколько увеличились. Если в 1926-1937 гг. среднегодовые темпы роста населения Западной Сибири составляли 1,8\%, а в 1937- 1939 гг. - около $1 \%$, то в $1939-1941$ гг. - 1,9\%.

Таблица 1. Численность населения Западной Сибири в 1939- 1941 гг. *

\begin{tabular}{l|c|c|c|c|c}
\hline \multirow{2}{*}{ Дата } & \multicolumn{3}{|c|}{ Тыс. человек } & $\begin{array}{r}\text { Соотношение городского и сельского } \\
\text { населения, \% }\end{array}$ \\
\cline { 2 - 6 } & $\begin{array}{c}\text { все } \\
\text { население }\end{array}$ & $\begin{array}{c}\text { городское } \\
\text { население }\end{array}$ & $\begin{array}{c}\text { сельское } \\
\text { население }\end{array}$ & городское & сельское \\
\hline 17.01 .1939 г. ${ }^{* *}$ & 8927,3 & 2581,8 & 6345,5 & 28,9 & 71,1 \\
01.01 .1940 г. ${ }^{* * *}$ & 9097,3 & 2730,3 & 6367,0 & 30,0 & 70,0 \\
01.01 .1941 г. ${ }^{* * *}$ & 9266,6 & 2792,6 & 6474,0 & 30,1 & 69,9 \\
1941 г. в \% к 1939 г. & 103,8 & 108,2 & 102,0 & - & - \\
\hline
\end{tabular}

Источник: Расчеты авторов на основе: РГАЭ. Ф. 1562. Оп. 20. Ед.xp. 241: 30, 53; РГАЭ. Ф. 1562. On. 336. Ед.хр. 226: Л. 3; РГАЭ. Ф. 1562. Оп. 336. Ед.хр. 311: 3; РГАЭ. Ф. 1562. Оп. 336. Ед.хр. 313: Л. 3.

Примечания: * - В границах Алтайского края, Новосибирской и Омской областей по административно-территориальному устройству 1941 г.; ** - перепись 1939 г.; *** - оценка ЦСУ Госплана СССР. 
Важной позитивной характеристикой трансформации людского потенциала Западной Сибири в 1939-1941 гг. стал перелом тренда численности сельского населения. После демографической «бури» начала - середины 1930-х годов, вызванной индустриализацией, коллективизацией и голодом, численность сельского населения вновь стала увеличиваться. В 1939-1941 гг. сельское население региона увеличилось на 2\% (таблица 1), что в абсолютном выражении составило почти 129 тыс. человек.

В основе роста численности сельского населения региона лежали, главным образом, высокая рождаемость, обусловленная значительной инерционностью демографических процессов, и как следствие - очень высокие показатели естественного прироста. Миграционный прирост сельского населения Западной Сибири, как и прежде, характеризовался отрицательными величинами. Из деревни уезжало больше людей, чем приезжало. Но масштабы бегства жителей деревни в города сократились. Определенную роль в преодолении миграционного хаоса играла общая стабилизация социальноэкономической ситуации. Большое значение имели мероприятия административного характера, сдерживающие отток жителей деревни в города. Ещё в декабре 1932 г. в СССР были введены паспортный режим и система прописки, которые были значительно ужесточены в 1940 г. Промышленные предприятия пытались внедрить систему организованного набора рабочей силы. Эти меры фактически означали прикрепление колхозников к колхозам, но объективно способствовали и некоторому упорядочению миграционных потоков. Соответственно повышенный естественный прирост компенсировал отрицательное сальдо миграции сельского населения. И если в годы первой и второй пятилеток отток жителей села в города полностью поглощал весь естественный прирост, то теперь кое-что оставалось для обеспечения численного роста жителей деревни.

Некоторую компенсирующую роль играло и плановое сельскохозяйственное переселение в Западную Сибирь из европейской части СССР, которое после длительного перерыва было возобновлено в мае 1939 г. В 1940 г. в Западную Сибирь прибыло 222 тыс. переселенцев [Платунов 1976: 238]. Кроме того, в регион продолжали прибывать десятки тысяч депортированных граждан. К 1 января 1940 г. число состоящих на учете западносибирских комендатур спецпоселенцев (в основном бывших кулаков) превысило 240 тыс. человек [Земсков 2005: 40-41]. В 1940 г. в СССР была проведена «зачистка» погранзоны, вследствие которой в Алтайский край было решено переселить 1743 немца, поляка, грека, китайца и корейца [Земсков 2005: 83]. В 1940-1941 гг. в Советском Союзе было осуществлено несколько крупных депортаций поляков. В Западную Сибирь к 1 апреля 1941 г. было депортировано почти 40 тыс. спецпоселенцев-поляков [Земсков 2005: 85]. В мае - июне 1941 г. власти организовали выселение «антисоветского элемента» из Литвы, Латвии, Эстонии, Молдавии, Западной Украины и Западной Белоруссии, из которых 48 тыс. человек оказались в Западной Сибири [Земсков 2005: 90-91]. Таким образом, спецпоселенцы играли значительную роль в наращивании людского потенциала западносибирского региона. По крайней мере, они частично нейтрализовали отток местных сельских жителей в города. Вместе с тем подобную ситуацию можно уподобить «тришкиному кафтану». Западная Сибирь действительно приобретала население, но районы первоначального проживания депортированных его теряли. 
На фоне повышения темпов роста численности сельского населения, темпы роста числа горожан Западной Сибири в 1939-1941 гг. несколько замедлились в сравнении с периодом первых пятилеток. Исходная масса горожан была уже достаточно велика. Это само по себе отражалось на скорости роста их численности. Но главная причина состояла в том, что теперь сельское население выделяло для города меньше мигрантов, чем раньше. Сталинская технология «индустриальной бури и натиска», характерная для первой и второй пятилеток, если и не исчерпала себя полностью, то применялась ограниченно. Освоение уже построенных фабрик и заводов требовало меньшего количества рабочих рук, чем их строительство.

Отметим, однако, незавершенность процессов урбанизации в Западной Сибири, что отражало незаконченность самого процесса индустриализации. Хотя уровень урбанизированности региона к началу 1941 г. по отношению к 1939 г. несколько повысился, большая часть сибиряков по-прежнему продолжали жить в сельской местности. Почти 70\% сибиряков проживали в деревне и так или иначе были связаны с аграрным производством. Особенно низким уровень урбанизированности оставался в преимущественно аграрном Алтайском крае. Здесь в январе 1941 г. доля горожан составляла всего 18\%. Несколько выше был уровень урбанизированности Омской области, где он достигал 21\%. В Новосибирской области (главным образом за счет Кузбасса) перед началом Великой Отечественной войны доля городского населения повысилась до $43 \%^{1}$. В самом Кузбассе удельный вес городского населения на начало 1941 г. приближался, по-видимому, к 60\%. Самыми крупными городами Западной Сибири в январе 1941 г. по-прежнему оставались Новосибирск (451 тыс. жителей), Омск (301 тыс.), Сталинск (178 тыс.), Барнаул (165 тыс.), Томск (149 тыс.), Кемерово (143 тыс.), Прокопьевск (115 тыс.) $)^{2}$.

В 1940 г. было отмечено резкое падение рождаемости, общий коэффициент рождаемости упал по отношению к 1939 г. более чем на 10\% (таблица 2). Таким образом, демографическая подсистема Западной Сибири в 1940 г. вступила в качественно новую стадию развития. К этому времени полностью исчерпал себя такой резерв повышения рождаемости, как запрет абортов, который был введен в 1936 г. Но женщины быстро приспособились к запретительным мерам. Страну охватила эпидемия подпольных абортов. Но самым главным фактором, отрицательно воздействовавшим на динамику рождаемости, стали причины скорее военно-политического, чем демографического характера. Основную роль играла форсированная подготовка страны к войне. Численность Красной армии после принятия 1 сентября 1939 г. «Закона о всеобщей воинской обязанности» стремительно нарастала. Отток мужчин бракоспособного возраста в армию означал временный, а в случае их гибели (боевые действия на озере Хасан, реке Халхин-Гол, в Западных Украине и Белоруссии, в советско-финляндской войне) - окончательный разрыв брачно-семейных отношений, а также резкое снижение числа потенциальных женихов. Число зарегистрированных браков уменьшалось. Если в 1938 г. на 1000 жителей Западной Сибири было зарегистрировано 10,8 брака, то в 1940 г. - всего 4,4 брака ${ }^{3}$ - снижение за 1938-1940

\footnotetext{
${ }^{1}$ РГАЭ. Ф. 1562. ОП. 20. Ед.хр. 241: 53.

2 РГАЭ. Ф. 1562. Оп. 20. Ед.хр. 241: 50.

${ }^{3}$ РГАЭ. Ф. 1562. Оп. 20. Ед.хр. 124: 1, 25, 41, 64, 72, 138, 158.
} 
гг. более чем в 2 раза. Снижение уровня брачности наблюдалось на всей территории региона, но в городских поселениях оно происходило не столь резко.

Таблица 2. Воспроизводство населения Западной Сибири в 1938-1940 гг.

\begin{tabular}{l|c|c|c|c}
\hline \multirow{2}{*}{ Год } & \multicolumn{2}{|c|}{ Рождаемость } & \multicolumn{2}{c}{ Смертность } \\
\cline { 2 - 5 } & $\begin{array}{c}\text { число родившихся, } \\
\text { тыс. человек }\end{array}$ & $\begin{array}{c}\text { общий коэффициент } \\
\text { рождаемости, \% }\end{array}$ & $\begin{array}{c}\text { число умерших, } \\
\text { тыс. человек }\end{array}$ & $\begin{array}{c}\text { общий коэффициент } \\
\text { смертности, \%о }\end{array}$ \\
\hline $1938 *$ & 364,0 & 40,8 & 179,7 & 20,1 \\
$1939 *$ & 374,7 & 42,0 & 179,1 & 20,1 \\
$1940 * *$ & 343,6 & 36,9 & 191,9 & 20,3 \\
1940 г. в \% к 1938 г. & 94,4 & 90,4 & 106,8 & 101,0 \\
1940 г. в \% к 1939 г. & 91,7 & 87,9 & 107,1 & 101,0
\end{tabular}

Источник: Расчеты авторов на основе: [Вестник статистики 1965: 88 - 89]; ГАРФ. Ф. А-374. Оп. 23. Ед.хр. 332: 9 об., 19, 74 об.; РГАЭ. Ф. 1562. Оп. 20. Ед.хр. 124: 1 - 160.

Примечания: * - По административно-территориальному устройству соответствуюших лет; ** _ по административно-территориальному устройству послевоенных лет.

Колебания брачности в условиях слитности брачного и репродуктивного поведения немедленно отражались на рождаемости. Исполняющий обязанности начальника Красноярского статистического управления Донской и начальник сектора населения и здравоохранения Каплун в докладной записке в Отдел демографии ЦСУ СССР 3 июня 1941 г. подчеркивали: «На снижение рождаемости оказало влияние и то обстоятельство, что во второй половине 1939 г. и в первой половине 1940 г. имели место события на МНР, в западных областях Украины и Белоруссии и в Финляндии. Вследствие чего значительная часть мужского населения нашего края длительное время отсутствовала, что, конечно, оказало некоторое действие на рождаемость в сторону её снижения» ${ }^{4}$

Одновременно в 1940 г. в Сибири дала о себе знать тенденция к повышению смертности. Она была обусловлена заметным ухудшением условий материального обеспечения жителей как городов, так и сельской местности. В результате естественный прирост в 1940 г. по отношению к 1939 г. сократился. Это значит, что в так называемый «предвоенный» период Сибирь втянулась в демографический кризис, который перерос в демографическую катастрофу периода Второй мировой войны.

\section{ЧИСЛЕННОСТЬ НАСЕЛЕНИЯ, 1941-1945 ГГ.}

Великая Отечественная война, кардинально изменившая условия развития населения Сибири, резко усилила воздействие факторов пертурбационного характера на демографическую подсистему общества. Военные годы также характеризовались рассогласованием социальных механизмов, регулирующих развитие народонаселения СССР. В итоге война исказила все без исключения демографические показатели. Прежде всего, это отразилось на динамике численности населения страны и её отдельных регионов.

\footnotetext{
${ }^{4}$ РГАЭ. Ф. 1562. ОП. 329. Ед.хр. 1871: 173.
} 
Для военных лет была характерна крайне неровная, а в определенном смысле хаотичная динамика численности населения Западной Сибири (таблица 3). Если в начале войны (с 1 июня 1941 г. по 1 января 1942 г.) численность населения Сибири росла, что было обусловлено притоком эвакуированных, то после 1942 г. и вплоть до мая 1945 г. она только сокращалась. Самое значительное снижение произошло в 1943 г., после чего темпы падения численности населения региона несколько замедлились, но преодолеть это падение не удалось до самого конца войны. Доминирующей тенденцией для всего периода было сокращение населения региона, с 1 июня 1941 г. по 1 мая 1945 г. его численность сократилась почти на $12 \%$.

Влияние пертурбационных факторов в сельской местности ощущалось значительно сильнее, чем в городах. Из таблицы 3 видно, что за период с 1 января 1941 г. по 1 сентября 1945 г. численность сельского населения Западной Сибири сократилась в 1,3 раза, что в абсолютном выражении составило почти 1,5 млн человек. При этом в 1941-1942 гг. число жителей западносибирской деревни за счет притока эвакуированных выросло на 3\% (на 216 тыс. человек), а в 1942-1945 гг. - сократилось сразу на 25\% (на 1674 тыс. человек).

\section{Таблица 3. Численность населения Западной Сибири в 1941-1945 гг.}

\begin{tabular}{l|c|c|c|c|c}
\hline \multirow{2}{*}{ Дата } & \multicolumn{3}{|c|}{ Тыс. человек. } & \multicolumn{2}{c}{$\begin{array}{c}\text { Соотношение городского и } \\
\text { сельского населения, \% }\end{array}$} \\
\cline { 2 - 6 } & $\begin{array}{c}\text { все } \\
\text { население }\end{array}$ & $\begin{array}{c}\text { городское } \\
\text { население }\end{array}$ & $\begin{array}{c}\text { сельское } \\
\text { население }\end{array}$ & городское & сельское \\
\hline 1 января 1941 г. & 9266,6 & 2792,6 & 6474,0 & 30,1 & 69,9 \\
1 января 1942 г. & 9921,4 & 3231,0 & 6690,4 & 32,6 & 67,4 \\
1 января 1943 г. & 9632,5 & 3423,4 & 6209,1 & 35,5 & 64,5 \\
1 января 1944 г. & 9069,3 & 3517,1 & 5552,2 & 38,8 & 61,2 \\
1 мая 1945 г. & 8541,9 & 3517,8 & 5024,1 & 41,2 & 58,8 \\
1 сентября 1945 г. & 8536,7 & 3520,3 & 5016,4 & 41,2 & 58,8 \\
1 сентября 1945 г., \% к 1 января 1941 г. & 92,1 & 126,1 & 77,5 & - & - \\
\hline
\end{tabular}

Источник: Расчеты авторов на основе: РГАЭ. Ф. 1562. Оп. 20. Ед.хр. 241: 53 - 54; РГАЭ. Ф. 1562. On. 20. Ед.xp. $403: 40$ об.; РГАЭ. Ф. 1562. Оп. 20. Ед.хр. 404: Л. 3; РГАЭ. Ф. 1562. Оn. 20. Ед.xp. 405: Л. 2; РГАЭ. Ф. 1562. On. 20. Ед.хр. 564: 2 об., 60 об.

Примечания: По административно-территориальному устройству текущих лет. Оиенка ЦСУ СССР, без армии, спеиконтингента и госпиталей.

Основным фактором, предопределившим сокращение численности сельского населения, были масштабные призывы и мобилизации мужского контингента в армию (в сельской местности в отличие от городов почти отсутствовала система брони для специалистов). Заметную роль играл отток населения, мобилизованного на работу в промышленность, на транспорт и стройки, а также молодежи, привлеченной к учебе в школах ФЗО, ремесленных и железнодорожных училищах. Существенное значение имело стихийное перемещение части жителей деревни в городские поселения. Отрицательно отражались на численности сельского населения региона административные преобразования сельских населенных пунктов в городские. Нельзя не учитывать и сокращение показателей естественного прироста (смертность в 1942 - 1944 гг. превышала рождаемость), а также активные реэвакуационные процессы. 
Сокращение численности сельского населения раскрывает «секрет» бурного, на первый взгляд, роста уровня урбанизации Западной Сибири в 1941-1945 гг. Удельный вес горожан в регионе повысился с 30,1\% на начало 1941 г. до 41,2\% на середину 1945 г. (таблица 3). Такое положение, однако, было обусловлено не столько увеличением численности горожан, сколько сокращением количества сельских жителей. Подобного рода «квазиурбанизация», несомненно, предопределялась аномальным влиянием факторов военного времени.

Соотношение темпов роста и сокращения численности городского и сельского населения, в конечном итоге, обусловила и эволюцию численности всего населения Западной Сибири. Для СССР первой половины XX века сокращение сельского населения явление достаточно обыденное, поскольку промышленный рост стимулировал миграции из деревни в город. Но в период «нормального», мирного развития количественное уменьшение сельского населения сопровождалось более быстрым ростом числа горожан и в то же время тормозилось высоким естественным приростом. В результате общая численность населения, как правило, возрастала. В годы войны ситуация была принципиально иной. Число жителей деревни очень резко сократилось. Естественный прирост характеризовался в основном отрицательными величинами. В результате факторы, в мирные годы способствующие компенсации падения численности сельского населения, не действовали. К тому же большинство выбывающих жителей деревни перемещались не в города, а в армию, т.е. за пределы региона. В итоге общая численность населения Западной Сибири с 1 января 1941 г. и до завершения Второй мировой войны (до 1 сентября 1945 г.) сократилась на 7,9\%. В абсолютном выражении это составило 729,9 тыс. человек (таблица $3)$.

Негативное влияние войны отразилось не только на численности, но и на составе населения. Ещё в довоенные годы в СССР, в том числе и в Сибири, сформировался дисбаланс полов, который в годы Великой Отечественной войны достиг наибольшего напряжения. Число и удельный вес женщин значительно превышали число и удельный вес мужчин. Так, в сельской местности Западной Сибири на 1 января 1943 г., согласно данным сельсоветского учета, доля мужчин в возрастной группе 18-24 года составляла менее 19\%, на 1 января 1945 г. - 21\%, в возрастной группе 25-49 лет - соответственно 20,4 и 20,2\% [Исупов 2008: 102].

Основным источником формирования глубоких диспропорций в составе населения Сибири по полу, как и по всей стране, была массовая мобилизация мужчин в армию, флот, пограничные и внутренние войска, а также гибель военнослужащих в ходе боевых действий. Как известно, призыв военнообязанных в Сибирском военном округе был развернут по Указу Президиума Верховного Совета СССР от 22 июня 1941 г [Великая Отечественная... 1985: 452]. Фронтовые соединения Красной армии из-за огромных боевых потерь убитыми, ранеными и пленными требовали все новых пополнений. В этой связи Государственный комитет обороны 10 августа 1941 г. принял постановление о проведении дополнительной массовой мобилизации военнообязанных [Великая Отечественная... 1985: 452]. К 1 декабря 1941 г. в Сибири было призвано в армию свыше 1843 тыс. человек, что составило 66\% от числа мужчин призывного возраста 18-45 лет. Западная Сибирь до конца 
1941 г. отдала вооруженным силам страны 1057 тыс. человек ${ }^{5}$. Поскольку в сельской местности система бронирования практически отсутствовала, удельный вес мобилизованных в деревне был значительно выше, чем в городе. Если в городе удельный вес призванных в армию к декабрю 1941 г. составлял 52\% мужчин призывного возраста, то в деревне - свыше $75 \%$.

Отметим еще одну характерную для Сибири особенность мобилизации призывного контингента в армию. Поскольку в регионе уровень урбанизированности (за исключением Кузбасса) был ниже, чем по России в целом, Сибирь отдала в Вооруженные силы страны (в относительном выражении) особенно много людей. Всего за 4 года войны (1941 - 1945 гг.) в Сибирском военном округе было мобилизовано свыше 2621 тыс. человек [Население России... 2001: 33].

Глубокие негативные изменения, происшедшие в структуре и численности населения Сибири, послужили серьезными факторами мощных демографических девиаций, отчетливо фиксируемых статистикой в 1941-1945 гг. Обратимся прежде всего к анализу воспроизводственных процессов.

Как видно из таблицы 4, в динамике смертности населения Сибири четко выделяются два периода: подъема смертности в 1941-1942 гг. и ее резкого спада ниже показателей довоенных лет в 1943-1945 гг.

Таблица 4. Рождаемость и смертность населения Сибири в годы Великой Отечественной войны, на 1000 человек *

\begin{tabular}{l|c|c|c}
\hline Год & Рождений & Смертей & Естественный прирост (убыль) \\
\hline 1941 & 33,2 & 21,2 & $+12,0$ \\
1942 & 22,0 & 26,0 & $-4,0$ \\
1943 & 12,5 & 18,4 & $-5,9$ \\
1944 & 12,1 & 12,9 & $-0,8$ \\
1945 & 15,6 & 9,0 & $+6,6$ \\
\hline
\end{tabular}

Источник: Расчеты авторов на основе: РГАЭ. Ф. 1562. Оп. 20. Ед.хр.251: 75- 76, 87 - 88, 126 - 127, 153 - 154, 156 - 157, 192 - 193, 204 - 205; РГАЭ. Ф. 1562. On. 20. Ед.xp. 418: 28 - 29, 35 - 36, 63 - 64, 96 - 97, 99 - 100, 135 - 136, 149 - 150, 187 - 188; РГАЭ. Ф. 1562. On. 20. Ед.xp. 501: 49 - 50, 55 - 56, 98 -99, $107-108,144-148,183-184,189-190,199-200,211-212,244-245$; РГАЭ. Ф. 1562. On. 20. Ед.xp. 577: 52 - 53, $58-59,104-105,119-120,156-158,160-161,195-196,201-202,211-212,223-224$; ГАНО. Ф. Р-11. Оп. 2. Ед.хр. 21: 7 об-8; ИсАОО. Ф. 2122. Оп. 1. Ед.хр. 1136: 92 об.; ГАКО. Ф. Р-304. On. 4. Ед.xp. 157: 7, 53, 77; ГАКО. Ф. P-304. On. 4. Ед.xp. 197: 24.

Примечание: *- По территории Западной и Восточной Сибири.

\section{СМЕРТНОСТЬ , 1941-1945 ГГ.}

Если повышение смертности при резком ухудшении условий жизни населения, активизации миграционных процессов выглядит вполне ожидаемым, то такое парадоксальное явление, как сокращение смертности населения тыловых районов страны,

\footnotetext{
${ }^{5}$ РГАЭ. Ф. 4372: 55.
}

${ }^{6}$ РГАЭ. Ф. 4372: 55. 
ведущей самую тяжелую в своей истории войну, заставляет уделить этому парадоксу самое пристальное внимание.

В основе повышенной смертности населения Сибири в 1942 г. лежали причины экзогенного происхождения, обусловленные ухудшением условий жизни, питания, санитарного обеспечения и медицинского обслуживания. Ведущее место среди них занимали туберкулез, воспаление легких и совокупность желудочно-кишечных заболеваний (гемоколит, гастроэнтероколит, токсическая диспепсия, дизентерия). Огромный вклад в повышение смертности вносили детские инфекционные заболевания: скарлатина, корь, дифтерия. Большую опасность для населения Сибири представляли сыпной и брюшной тиф, а также паратиф.

В период 1943-1945 гг. наблюдается принципиально иная структура смертности населения. Так, по Алтайскому краю к 1945 г. доля смертности от желудочно-кишечных заболеваний сократилась в сравнении с 1942 г. с 13, до 3,6\%; тогда как доля туберкулеза выросла с 14,1 до $20 \%^{7}$; доля болезней сердца возросла соответственно с 12,3 до $16,7 \%$ [Исупов 2008: 139].

Схожие изменения произошли и в структуре детской смертности. В Новосибирской области в 1941 г. от желудочно-кишечных заболеваний умирало 33\% младенцев, от воспаления легких $-28,2 \%$, от острых детских инфекций $-10,8 \%$, от врожденной слабости и пороков развития - 4,6\%. В 1945 г. умирало от желудочно-кишечных болезней 20,6 \%, от болезней органов дыхания (в том числе туберкулеза) $33,1 \%$, от острых детских инфекций $5,9 \%$, от врожденной слабости и пороков развития $10 \%$.

Таким образом, в 1943-1945 гг. структура смертности населения качественно изменилась. Значение желудочно-кишечных и других инфекционных заболеваний в формировании смертности сокращается в несколько раз. Из основных причин смертности населения они превращаются во второстепенные.

Опираясь на вышеизложенные замечания, попытаемся реконструировать процессы, обусловливавшие динамику смертности в военные годы. Показатели смертности обрели тенденцию к повышению с первых же недель войны. Если в июне 1941 г. в городах Сибири уровень смертности составлял 20,4\%, то в июле - 24,6\%, в сельской местности соответственно 17,0 и 21,3\%. В значительной степени рост уровня смертности летом 1941 г. можно отнести за счет её сезонных колебаний, которые были типичны для СССР в первой половине XX века вследствие неизбежных в то время летних подъемов желудочнокишечной заболеваемости. С приходом холодов желудочно-кишечные болезни отступали и смертность, как правило, снижалась. Об этом свидетельствует, в частности, общее снижение смертности в регионах Западной Сибири в сентябре 1941 г. Так, в Алтайском крае смертность в сентябре снизилась по сравнению с августом на 4,2 \%о, в Новосибирской области - на 2,2\%, в Омской области - на 2,4\%о [Исупов 2008: 112]. Однако этот едва наметившейся тренд был вскоре перекрыт воздействием негативных факторов военной поры (резким ухудшением условий жизни, увеличением социально незащищенных групп

\footnotetext{
${ }^{7}$ ГААК Ф. Р-762: 9.

${ }^{8}$ ГАНО Ф. Р-29. ОП. 1. Ед.хр. 244: 8; ГАНО Ф. Р-1682. Л.13. 
населения, неблагоприятным для эпидемической обстановки воздействием эвакуации и др.), и обычного снижения смертности в осенне-зимний период не произошло.

Определяющей причиной подъема смертности в этот период был взрывной рост заболеваемости населения, причиной которой послужили усилившиеся миграционные процессы и прежде всего - эвакуация. Повышенная контактность в пути, антисанитария, слабая организация медицинского обслуживания в дороге создали благоприятные возможности для распространения различного рода инфекций. Мощность протекания эпидемического процесса во время транспортировки граждан была колоссальной.

Государство пыталось нейтрализовать действие этой угрозы. В ведение специально созданных для обслуживания эвакуации учреждений - эвакопунктов, входило и медикосанитарное обслуживание: выявление и изолирование всех больных и подозрительных с острозаразными заболеваниями; осуществление санитарно-профилактических мероприятий (дезинфекция); прививки против желудочно-кишечных и инфекционных заболеваний [Во имя Победы... 2005: 288]. К сожалению, в силу ряда причин, прежде всего новизны поставленных задач, недостаточного материально-технического обеспечения, а также нехватки приспособленных помещений они не смогли организовать в достаточной мере санитарное обслуживание эвакуированных, прежде всего санитарную обработку. Так, даже в январе 1942 г. такой крупный эвакопункт, как новосибирский, из поступивших 21353 эвакуированных смог провести санитарную обработку лишь 6026, то есть 28\% [Во имя Победы... 2005: 210-211].

О ситуации с заболеваемостью можно судить по таблице 5.

Таблица 5. Заболеваемость населения Западной Сибири в 1940 - 1945 гг., количество случаев

\begin{tabular}{|c|c|c|c|c|c|c|c|}
\hline \multirow{2}{*}{ Вид инфекции } & \multicolumn{6}{|c|}{ Год } & \multirow{2}{*}{ Итого } \\
\hline & 1940 & 1941 & 1942 & 1943 & 1944 & 1945 & \\
\hline Сыпной тиф & 2442 & 4637 & 16598 & 14657 & 24019 & 14147 & 74058 \\
\hline Брюшной тиф & 4788 & 4783 & 15215 & 13510 & 7048 & 8299 & 48855 \\
\hline Дизентерия & 20760 & 20025 & 27157 & 17886 & 6845 & 4937 & 76830 \\
\hline Дифтерия & 5737 & 6105 & 11469 & 9433 & 5778 & 4469 & 37254 \\
\hline Скарлатина & 7839 & 11879 & 18464 & 5642 & 4323 & 13130 & 53438 \\
\hline Корь & 59547 & 62791 & 42501 & 8077 & 17584 & 44654 & 175607 \\
\hline
\end{tabular}

Источник: [Семенов 2015: 235].

Как видим, в 1941-1942 гг. происходит увеличение распространения большинства инфекций в несколько раз, следствием чего и явилось увеличение общего коэффициента смертности населения Сибири в 1941-1942 гг. на 21,5\%.

На фоне увеличения общих коэффициентов смертности обращает внимание особенно резкий рост показателей младенческой смертности. Только в Западной Сибири в июне 1941 г. на 1000 родившихся умерло 209 детей в возрасте до 1 года, в июле - 326, в августе - 379 детей [Исупов 2008: 115]. Особенно внушительных величин показатели младенческой смертности достигли летом 1942 г., когда трагически совпало влияние двух негативных факторов: климатического (константного) и военно-политического (ситуационного). С одной стороны, очевидна полная зависимость младенческой смертности от обычных для того времени сезонных колебаний желудочно-кишечной 
заболеваемости (типичное летнее повышение). С другой, - на динамику младенческой смертности мощное повышающее воздействие оказали пертурбационные факторы войны. В итоге младенческая смертность достигла катастрофических величин. В июне 1942 г. коэффициент младенческой смертности повысился до 522\%о, в июле - до 612\%о [Исупов 2008: 115]. Это значит, что погибало свыше 60 младенцев из каждых 100 родившихся. Никогда ранее Сибирь не знала столь высоких показателей младенческой смертности.

В конце 1942 - начале 1943 г. демографическая подсистема Сибири вступила в качественно новую стадию развития. С этого времени уровень смертности населения тыловых районов СССР стал быстро сокращаться. В 1945 г. общий коэффициент смертности гражданского населения Сибири понизился по отношению к 1942 г. почти в 3 раза (таблица 4). Уже в 1943 г. показатели смертности были заметно ниже, чем в 1940 г. Если в 1940 г. общий коэффициент смертности в Сибири составлял 20,1\%о [Исупов 1992: 188], то в 1943 г. - 18,4\%о (таблица 5). Столь бурный процесс сокращения показателей смертности был во многом обусловлен снижением младенческой смертности. Так, в Западной Сибири в течение 1942-1945 гг. коэффициент детской смертности сократился более чем в 4 раза, в том числе в городах - почти в 4 раза, в сельской местности - почти в 5 раз [Исупов 2010: 76].

Причины такого явления многообразны. Позитивную роль сыграл целый комплекс факторов социокультурного, политического и демографического характера. Сложившаяся в 1941-1942 гг. эпидемическая ситуация в тылу вызывала серьезную обеспокоенность властей. Рост инфекций, перераставших по некоторым видам заболеваний в эпидемии, являли собой угрозу как укомплектованию армии личным составом, так и военному производству. Число людей, не подлежавших воинским и трудовым мобилизациям из-за состояния здоровья, а также потери рабочего времени в связи с утратой трудоспособности стремительно нарастали. Так, по заводу №166 (Омск) в 1942 г. временная нетрудоспособность на 100 работающих составляла по гриппу 180 дней, по гнойничковым заболеваниям кожи 67 дней, по туберкулезу легких 34 дня, по острым желудочнокишечным болезням 117 дней 9 .

Выстраивая социально-демографическую политику, властные органы исходили из того неоспоримого факта, что кардинально изменить в лучшую сторону условия труда и быта людей в военные годы невозможно. Война, таким образом, вынудила власти реализовать целый комплекс мероприятий, направленных на предотвращение распространения инфекций и излечение уже заболевших граждан.

В 1943-1945 гг. произошел резкий рост финансирования здравоохранения. Так, в Алтайском крае за годы войны финансирование здравоохранения выросло с 49,8 млн рублей в 1941 г. до 77,6 млн рублей в 1945 г. ${ }^{10}$. Расширилась сеть медицинских учреждений, в частности противоэпидемических. Если в 1941 г. на территории современных Новосибирской, Кемеровской, Томской областей насчитывалось 14 санэпидстанций, то в

\footnotetext{
${ }^{9}$ ИсАОО. Ф. 1143: 55.

${ }^{10}$ ГААК. Ф. Р-726: 10. 
1945 г. - 71 санэпидстанция ${ }^{11}$. Большое значение имело внедрение прогрессивных методов лечения, использование новых лекарственных средств, в том числе таких мощных, как сульфаниламид.

Несмотря на неблагоприятную эпидемическую обстановку, в годы войны резко снизилась заболеваемость по болезням желудочно-кишечного тракта (брюшной тиф, дизентерия, острые гастроэнтероколиты, токсическая диспепсия и др.). Для того чтобы понять их динамику в целом, рассмотрим их движение в двух регионах, значительно отличающихся по социально-экономическим условиям: в Кемеровской области и Алтайском крае (таблица 6).

Из таблицы 6 видно, что общим направлением было ежегодное снижение. Следует отметить, что процесс этот начался еще в довоенные годы и во многом нивелировал возникшие в связи с войной негативные факторы. Рост числа заболеваний наблюдался лишь по дизентерии в 1942 г. За 1942-1944 гг. снизилась в 3-4 раза заболеваемость болезнями желудочно-кишечного тракта. Отмечаемое исследователями снижение числа детей (наиболее восприимчивых к болезням желудочно-кишечного тракта), а как следствие снижение их контактности ${ }^{12}$, по всей видимости, может рассматриваться лишь как второстепенный фактор, так как снижение числа болезней желудочно-кишечного тракта началось еще до войны и, следовательно, до уменьшения количества детей.

Таблица 6. Динамика заболеваемости болезнями желудочно-кишечного тракта населения в Алтайском крае и Кемеровской области, 1940-1945, число случаев

\begin{tabular}{l|l|r|r|r|r|r|r}
\hline \multirow{2}{*}{ Вид болезни } & \multirow{2}{*}{ Край, область } & \multicolumn{6}{|c}{ Год } \\
\cline { 3 - 8 } & Алтайский & 1940 & 1941 & 1942 & 1943 & 1944 & 1945 \\
\hline \multirow{2}{*}{ Дизентерия } & Кемеровская & 5187 & 3063 & 3660 & 2350 & 982 & 712 \\
\multirow{2}{*}{ Токсическая диспепсия } & Алтайский & 3700 & 2737 & 1761 & 706 & 316 & 287 \\
\multirow{2}{*}{ Острый гастроэнтероколит у } & Кемеровская & - & - & 1595 & 603 & 473 & 636 \\
детей до 2-х лет & Алтайский & 45737 & 26821 & 24630 & 12834 & 7499 & 7467 \\
& Кемеровская & - & - & 16286 & 7694 & 4711 & 4568 \\
\hline
\end{tabular}

Источник: [Семенов 2015: 251].

Учитывая общий перелом, наступивший в эпидемических процессах болезней этой группы, можно предположить наличие единой действующей силы на тот или иной элемент эпидемического процесса. Следует отвергнуть возможность уменьшения слоя восприимчивого населения в результате вакцинации, так как дизентерия, давшая наиболее показательное снижение, имела крайне неэффективную вакцину, не способную его обеспечить. Не произошло в годы войны и кардинального улучшения санитарного благоустройства и санитарного контроля, способного нарушить механизм передачи возбудителей инфекций в масштабах, соответствующих подобному спаду.

\footnotetext{
${ }^{11}$ ГАНО Ф. Р-11. ОП. 2. Ед.хр. 611: 4; ГАНО Ф. Р-11. Оп. 2. Ед.хр. 1179: 9-13 об.; ГАКО Ф. Р-304. Оп. 1. Ед.хр. 162: 30-34 об.; ГАТО Ф. Р-1005: 5-9 об.

12 Прямая зависимость между снижением числа детей и числа болезней не находит подтверждения, так как изменяются (снижаются) и относительные показатели заболеваемости на 10 тыс. человек, в том числе на 10 тыс. у детей до 2-х лет, что простым снижением числа детей объяснено быть не может.
} 
По всей видимости, хорошо распознаваемые симптомы (понос, температура), которые служили достаточным основанием для госпитализации, привели к серьезному удару по резервуару этой группы инфекций. Косвенные признаки этого мы находим в изменении эпидемиологии этих болезней. Основной возбудитель дизентерии в 30 -е годы (бактерия Григорьева-Шига) в годы войны фактически исчезает, уступая место бактерии Флесперса. Бактерия Флесперса вызывала дизентерию с более мягким течением и имела большие шансы быть перенесенной человеком без обращения к медикам, что позволило ей сохранить свою популяцию. Таким образом, меры, предпринимаемые советским здравоохранением, привели к значительному сокращению мощности эпидемического процесса. Сокращение заболеваемости естественно привело к снижению смертности населения от желудочно-кишечных болезней, что составляло одну из главных основ советского демографического чуда - снижения смертности тылового населения в годы войны в несколько раз.

Увеличение сети лечебных учреждений, приближение ее к населению, улучшение качества медицинского обслуживания, медикаментозного снабжения, внедрение передовых методов лечения привели также и к снижению летальности.

Таблица 7. Летальность в больницах Новосибирской области, в границах 1945 г., в процентах к общему количеству больных

\begin{tabular}{l|c|c|c}
\hline & 1943 г. & 1944 г. & 1945 г. \\
\hline Больницы в городах и рабочих поселках & 5,5 & 3,3 & 2,2 \\
Сельские больницы & 3,0 & 2,4 & 1,6 \\
\hline
\end{tabular}

Источник: ГАНО. Ф. Р-29. Оп. 1. Ед.хр. 183: 6 об.

Снижение происходило за счет инфекционных, терапевтических и общих отделений больниц, т.е. также имело в своей основе снижение летальности у больных острыми инфекционными и желудочно-кишечными заболеваниями ${ }^{13}$.

Благодаря сочетанию этих факторов, в течение 1943-1945 гг. показатели смертности от брюшного тифа, дифтерии, гемоколита, кори и коклюша снизились в 2 раза, от туберкулеза легких - в 1,9 раза, от воспаления легких - в 3,3 раза, от токсической диспепсии - в 3,7 раза, а от дизентерии - в 6 раз [Алексеев, Исупов 1986: 138].

В тоже время восприимчивость сибиряков к инфекциям, обусловленная низким уровнем жизни, оставалась крайне высокой. Поэтому, несмотря на огромные усилия медиков, заболеваемость рядом болезней продолжала оставаться высокой в течении всей войны. Бедствием военных лет оставался туберкулез - заболевание ярко выраженной социальной окраски. Смертность от туберкулеза, сосредоточившись в молодых и средних возрастных группах, в основном от 20 до 49 лет, уносила жизни самых работоспособных людей.

Таким образом, социально-демографическая политика государства принесла результаты. Она позволила на фоне нищенского уровня материального обеспечения тыловиков, истощенности защитных сил человеческих организмов, неблагоприятной

${ }^{13}$ ГАНО. Ф. Р-29. Оп. 1. Ед.хр. 183: 6 об. 
эпидемической обстановки снизить заболеваемость по ряду важнейших болезней путем повышения эффективности здравоохранения и максимального ужесточения санитарного контроля. Это наряду с понижением летальности привело к уменьшению показателей общей смертности более чем в 2 раза по сравнению с мирными, довоенными годами.

\section{РОЖДАЕМОСТЬ В 1941-1945 ГГ.}

Узловым элементом воспроизводства населения является рождаемость, которая в военные годы сократилась до предельно низких величин. Общий коэффициент рождаемости в Сибири (см. таблицу 4) в целом за годы войны (1941-1945 гг.) уменьшился более чем в 2 раза, в том числе в 1941-1942 гг. индекс рождаемости в регионе понизился в 1,5 раза, в 1942-1943 гг. - в 1,7 раза. В 1943-1944 гг., достигнув низшей точки, уровень рождаемости стабилизировался. Перелом тренда произошел только в 1945 г. С этого времени показатели рождаемости стали медленно увеличиваться. Но в целом за все годы Великой Отечественной войны, по прикидочным расчетам с использованием методики, предложенной известным советским демографом Б.Ц. Урланисом [1960], в Сибири родилось примерно на 1 млн детей меньше, чем это можно было ожидать гипотетически [Алексеев, Исупов 1986: 95].

Таблица 8. Рождаемость городского и сельского населения Западной и Восточной Сибири, число родившихся на 1000 человек населения

\begin{tabular}{l|c|c}
\hline Год & Городские поселения & Сельские местности \\
\hline 1941 & 34,6 & 32,5 \\
1942 & 23,8 & 19,8 \\
1943 & 14,9 & 11,2 \\
1944 & 16,2 & 10,1 \\
1945 & 20,1 & 12,8 \\
1945 в \% к 1941 & 58,1 & 39,4 \\
\hline
\end{tabular}

Источник: [Алексеев, Исупов 1986: 88].

В мирные годы, как правило, уровень рождаемости в сельской местности выше, чем в городах. Сельская семья в большей степени, чем городская, ориентирована на многодетность. Но война значительно деформировала процесс воспроизводства населения (см. таблицу 8) и, являясь мощным пертурбационным фактором, исказила естественный ход событий. Обычное для мирного периода соотношение рождаемости в городах и селах было грубо нарушено. В городах уровень рождаемости был выше, чем в деревне.

В сельской местности особенно резкими были и темпы падения рождаемости. В городах этот процесс протекал относительно плавно. В 1941-1945 гг. общий коэффициент рождаемости сократился в городских поселениях Сибири на 42\%, тогда как в деревне почти - на 61\% (таблица 8). Рождаемость в сельской местности снижалась так быстро, что уже в 1942 г. уровень рождаемости в городских поселениях заметно превышал аналогичные показатели по сельской местности. К тому же в городах перелом тренда рождаемости в сторону повышения произошел уже в 1944 г., тогда как в сельской местности - на год позднее. Помимо этого, в крупных городах рождаемость была выше, чем в целом по городским поселениям Сибири. И если в городах Сибири в целом в 1943 г. общий коэффициент рождаемости составлял 14,9\%о, то в Сталинске - 17,2\%, в Прокопьевске - 
$18,0 \%{ }^{14}$. В Новосибирске в годы войны уровень рождаемости вообще не опускался ниже $19 \%{ }^{15}$.

Особенности динамики рождаемости в 1941-1945 гг., различия в рождаемости в городах и сельской местности, в крупных и небольших по численности населения городских поселениях определялись главным образом мощным воздействием внешних по отношению к демографической подсистеме факторов, обусловивших кардинальные девиации половозрастного состава населения. Уход женатых мужчин в армию означал временный, а в случае гибели бойца окончательный разрыв уже установившихся брачносемейных отношений. Кроме того, война вызвала масштабный процесс овдовения женщин. Призыв в Красную армию молодых людей стал причиной снижения числа потенциальных женихов, что в свою очередь привело к резкому сокращению количества заключаемых браков.

В Сибири в 1942 г. по отношению к 1941 г. общий коэффициент брачности сократился в 2,2 раза (таблица 9). В 1943 г. общий коэффициент брачности понизился до минимальных за всю войну величин, что совпало с самой низкой точкой падения рождаемости. Это говорит о том, что структурные факторы, в частности дисбаланс полов, были одной из основных причин формирования демографической ямы военных лет. Медленное нарастание брачности началось только в 1944 г., когда в тыловых районах страны скопилось некоторое количество фронтовиков-инвалидов, комиссованных по состоянию здоровья из армии. Довоенный уровень брачности в Сибири был превышен только в конце 1945 г., когда развернулись процессы демобилизации.

Таблица 9. Брачность населения Сибири, 1941-1945, на 1000 человек населения*

\begin{tabular}{c|c|c|c|c|c|c}
\hline \multirow{2}{*}{ Год } & \multicolumn{3}{|c|}{ Браки } & \multicolumn{3}{c}{ Разводы } \\
\cline { 2 - 7 } & $\begin{array}{c}\text { городские } \\
\text { поселения }\end{array}$ & $\begin{array}{c}\text { сельская } \\
\text { местность }\end{array}$ & всего & $\begin{array}{c}\text { городские } \\
\text { поселения }\end{array}$ & $\begin{array}{c}\text { сельская } \\
\text { местность }\end{array}$ & всего \\
\hline 1941 & 7,6 & 3,3 & 4,7 & 0,6 & 0,2 & 0,3 \\
1942 & 3,4 & 1,8 & 2,7 & 0,6 & 0,2 & 0,3 \\
1943 & 3,2 & 1,8 & 2,3 & 0,5 & 0,2 & 0,3 \\
1944 & 4,9 & 2,6 & 3,6 & 0,4 & 0,2 & 0,3 \\
1945 & 9,6 & 5,7 & 6,4 & $0,0^{* *}$ & $0,0^{* *}$ & $0,0^{* *}$ \\
\hline
\end{tabular}

Источники: [Алексеев, Исупов 1986: 101; Исупов 1991: 165].

Примечания: *- По административно-территориальному устройству соответствующих лет; **величина менее $0,1 \%$.

Отметим еще одну явно нетипичную для мирных лет характеристику брачности в военные годы. Уровень брачности в городах был выше, чем в сельской местности, поскольку города обладали некоторым «запасом» женихов. Здесь сосредотачивались тяжелые и добывающие отрасли экономики с трудившимися здесь забронированными мужчинами. В городах также располагались эвакогоспитали. Выздоравливавшие бойцы и офицеры Красной армии считались «завидными» женихами.

\footnotetext{
${ }^{14}$ ГАКО. Ф. Р-304. ОП. 4. Ед.хр. 157: 7.

${ }^{15}$ ГАНО. Ф. Р-11. ОП. 2. Ед.хр. 871: 3. 
Изменения количественных параметров брачности сопровождались заметными структурными сдвигами. В условиях острого дефицита женихов процесс формирования семей существенно изменился, причем в сторону развития аномальных тенденций, не характерных для периода мирных лет. Рассмотрим эти процессы на материалах Западной Сибири (таблица 10).

Таблица 10. Возрастная структура женихов и невест в Западной Сибири, 1941-1943, \%

\begin{tabular}{l|c|c|c|r}
\hline \multirow{2}{*}{ Возраст женихов и невест, лет } & \multicolumn{2}{|c|}{1941 г. } & \multicolumn{2}{c}{1943 г. } \\
\cline { 2 - 5 } & мужчины & женщины & мужчины & женщины \\
\hline Моложе 18 & 0,1 & 0,7 & 0,4 & 0,9 \\
$18-19$ & 11,6 & 20,2 & 5,6 & 46,2 \\
$20-24$ & 28,0 & 38,7 & 38,1 & 16,7 \\
$25-29$ & 34,8 & 21,1 & 27,1 & 8,1 \\
$30-34$ & 14,8 & 9,3 & 13,6 & 3,4 \\
$35-39$ & 6,5 & 4,5 & 6,2 & 3,6 \\
40 лет и старше & 4,1 & 5,3 & 8,8 & 0,4 \\
Возраст неизвестен & 0,1 & 0,2 & 0,2 & 100,0 \\
Всего & 100,0 & 100,0 & 100,0 & \\
\hline
\end{tabular}

Источник: Расчеты авторов на основе: ГАНО. Ф. Р-11. Оп. 2. Ед.хр. 607: 63 - 63 об.; ГАНО. Ф. Р-11. On. 2. Ед.xp. 871: 22 - 22 об., 33 - 33 об.; ГАКО. Ф. Р-304. Оп. 4. Ед.xp. 157: 27 - 27 об.; ИсАОО. Ф. 2122. On. 1. Ед.xp. 1134: 95 - 95 об; ИсАОО. Ф. 2122. Оп. 1. Ед.хр. 1137: 70 - 70 об.; ТА ГКС АК.

Прежде всего, укажем на сокращение доли женщин, выходивших замуж в возрасте старше 24 лет. Женская брачность переместилась в младшие возрастные группы до 24 лет. Девушки спешили оформить брак, пока «капризный» из-за своей дефицитности жених был согласен идти в загс. Вместе с тем женщины чаще, чем в мирное время, выходили замуж за ровесников. Увеличилось количество браков девушек с мужчинами значительно старше и младше себя.

Таблица 11. Число разводов в городах Западной Сибири в 1939-1945 гг., на 1000 человек населения

\begin{tabular}{l|c|c|c|c|c|c|c}
\hline Год & $\begin{array}{c}\text { Алтайский } \\
\text { край }\end{array}$ & $\begin{array}{c}\text { Омская } \\
\text { область }\end{array}$ & $\begin{array}{c}\text { Новосибирская } \\
\text { область }\end{array}$ & $\begin{array}{c}\text { Кемеровская } \\
\text { область }\end{array}$ & $\begin{array}{c}\text { Томская } \\
\text { область }\end{array}$ & $\begin{array}{c}\text { Тюменская } \\
\text { область }\end{array}$ & Итого \\
\hline 1939 & 0,64 & 0,86 & 0,55 & - & - & - & 0,68 \\
1940 & 0,71 & 1,25 & 0,83 & - & - & - & 0,93 \\
1941 & 0,53 & 0,92 & 0,51 & - & - & - & 0,65 \\
1942 & 0,51 & 0,89 & 0,49 & - & - & - & 0,63 \\
1943 & 0,72 & 0,87 & 0,76 & 0,46 & - & 0,70 \\
1944 & 0,52 & 0,86 & 0,55 & 0,35 & 0,65 & 0,79 & 0,62 \\
1945 & 0,03 & 0,05 & 0,06 & 0,03 & 0,15 & 0,10 & 0,07 \\
\hline
\end{tabular}

Источник: Расчеты авторов на основе: ГАРФ. Ф. А-374. Оп. 23. Ед.хр. 455: 1, 24.; ГАРФ. Ф. А-374. On. 11. Ед.xp. 39: 3, 5.; ГАРФ. Ф. A-374. On. 11. Ед.xp. 40: 3.; ГАРФ. Ф. A-374. On. 11. Еd.xp. 77: 3, 69, 73.; ГАРФ. Ф. А-374. On. 11. Ед.xp. 176: 2, 62.; ГАРФ. Ф. A-374. On. 11. Ед.xp. 225: 3, 36, 82.; ГАРФ. Ф. А374. On. 11. Ед.xp. 293: 3, 81.; ГАРФ. Ф. A-374. On. 11. Еd.xp. 294: 11, 69, 76.; ГАРФ. Ф. A-374. On. 11 Ед.xp. 380: 2, 75, 127, 178, 182.; ГАНО Ф. P-11. On. 2. Ед.xp. 607: 18, 51.; ГАНО Ф. Р-11. On. 2. Ed.xp. 736: 2, 4, 21.; ГАНО Ф. P-11. On. 2. Ед.xp. 871: 26, 27.; ГАНО Ф. P-11. On. 2. Ed.xp. 992: 19, 20.

Изменилось и брачное поведение мужчин. Переизбыток невест привел к заметному увеличению доли сверхранних браков мужчин. Брачность юношей в возрасте моложе 18 лет повысилась сразу в 4 раза. Вместе с тем более чем удвоился удельный вес «женихов» в 
возрасте старше 40 лет. Тыловики старших возрастов получили возможность брать в жены молодых девушек. Девиации в брачном поведении мужчин и женщин свидетельствуют, что институт семьи в военные годы переживал кризис.

Общий коэффициент разводимости в военные годы вплоть до конца 1944 г. сохранялся без каких-либо существенных изменений. Но это не значит, что семьи были крепкими. Подавляющее большинство мужчин находились в армии. Это делало оформление развода невозможным. Все разводы приходились на немногочисленную когорту мужчин, оставшихся в тылу. Исходя из этого, вполне реально предположение, что количество распавшихся семей в 1941-1944 гг. увеличилось. Но фактический развод не регистрировался и, следовательно, не попадал в статистическую отчетность. Аномально крутое падение индекса разводимости статистически фиксируется только в 1945 г. Он понизился сразу до величины менее $0,1 \%$ (таблица 11). Снижение показателя разводимости было очевидным результатом административных решений советского правительства, не учитывавших сложную ситуацию на брачном рынке. Президиум Верховного Совета СССР 8 июля 1944 г. принял указ «Об увеличении государственной помощи беременным женщинам, многодетным и одиноким матерям, усилении охраны материнства и детства, об установлении почетного звания «Мать героиня» и учреждении ордена «Материнская слава» и медали «Медаль материнства» [Сборник законов... 1968: 409-417]. Процедура развода была резко усложнена. Отныне развод производился только через суд, публично, с привлечением свидетелей. Эти требования были обязательными даже при обоюдном согласии супругов, отсутствии у них детей и имущественных споров. Число официально оформленных разводов в 1944-1945 гг. действительно сократилось. Но количество распавшихся семей от этого не уменьшилось. Как правило, муж и жена де-факто жили раздельно, но не оформляли развод де-юре.

Президиум Верховного Совета СССР, издав указ от 8 июля 1944 г., в сущности, поощрял внебрачное сожительство. Указ отменил право женщины на обращение в суд с иском об установлении отцовства и взыскании алиментов на содержание ребенка, родившегося от лица, с которым она не состоит в зарегистрированном браке. Отныне советское брачно-семейное законодательство признавало только официально зарегистрированный брак. Установление отцовства в отношении ребенка, родившегося вне зарегистрированного брака, не допускалось даже в случае, если мужчина добровольно признавал себя отцом. Детям, родившимся вне брака, в свидетельстве о рождении в графе «отец» ставился прочерк. Мужчины, освобожденные от алиментных обязательств, могли вступать во внебрачные отношения без каких-либо последствий. В условиях острого «дефицита женихов» внебрачное сожительство не могло не получить широкого распространения.

Число внебрачных рождений во втором полугодии 1944 г. резко увеличилось. Так, в Кемеровской области во втором полугодии 1944 г. по отношению к первому полугодию этого года количество внебрачных детей выросло более чем в 8 раз ${ }^{16}$. В Томской области в 1945 г. число детей, в метрических свидетельствах которых отсутствовала запись об отце,

${ }^{16}$ ГАКО. Ф. Р-304. Оп. 4. Ед.хр. 157: 33 об. - 34 об. 


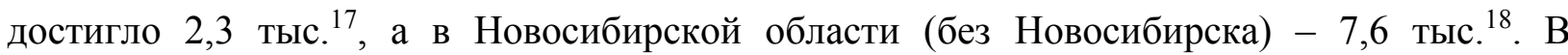
Алтайском крае в 1945 г. прочерк в графе «отец» поставлен в свидетельствах о рождении 8,4 тыс. младенцев ${ }^{19}$. Однако компенсировать огромные военные потери, прибегая к административным и фактически аморальным технологиям, было невозможно.

Итак, в годы Великой Отечественной войны на передний план в детерминации демографических процессов выступили структурные факторы. Однако было бы ошибочно связывать падение рождаемости в военные годы исключительно с деформациями половозрастного состава населения. Анализ архивных документов подтверждает, что в тех семьях, где брачные связи не прерывались, количество родившихся детей сократилось. Репродуктивные установки, направленные на многодетность, блокировались ухудшением условий жизни. Сохранившиеся брачные пары откладывали рождение детей до завершения войны. В период войны уровень брачной рождаемости в сибирском регионе уменьшился почти в 3 раза [Алексеев, Исупов 1986: 104].

Главным способом контроля над рождаемостью в условиях почти полного отсутствия средств контрацепции не могло не стать искусственное прерывание беременности. В годы войны была продолжена линия репродуктивного поведения, зародившаяся еще в конце 1920-х - в 1930-е годы. Распространение абортов в Западной Сибири, особенно в крупных городах, несмотря на категорический запрет и уголовное преследование, было достаточно широким. В январе 1942 г. начальник УНКВД по Алтайскому краю Волошенко и заместитель начальника Управления НКВД по Алтайскому краю Осипов в докладной записке «О работе органов милиции», направленной в Алтайский крайком ВКП(б), писали: «С начала войны и до 30. XI. 41 г. по краю было зарегистрировано и раскрыто 50 случаев криминальных абортов, за которые привлечен 51 человек» ${ }^{20}$. Уполномоченный Госплана СССР по Новосибирской области, руководитель областного статистического управления И.В. Жатов в конце 1944 г. докладывал в Новосибирский обком ВКП(б): «Снижение рождаемости в 1943 и 1944 военных годах есть результат резкого сокращения численности трудоспособного мужского населения. Кроме того, на снижение рождаемости повлияло значительное количество произведенных в городах области абортов» ${ }^{21}$.

Из-за недостатка и дефектности статистических материалов военных лет невозможно определить собственно коэффициенты воспроизводства населения. Поэтому мы вынуждены использовать показатель, имеющий ограниченные аналитические возможности, а именно материалы по естественному приросту населения. Таблица 4 демонстрирует главную тенденцию динамики демографической сферы региона: естественный прирост в 1942-1944 гг. характеризовался отрицательными величинами. В эти годы смертность превышала рождаемость, что является основным свидетельством обрушившейся на страну и её отдельные территории депопуляции. Поскольку коэффициент

\footnotetext{
${ }^{17}$ ГАТО. Ф. $1085 \ldots: 9$ об.

${ }^{18}$ ГАНО. Ф. Р-11. Оп. 2. Ед.хр. 992: 13, 41.

19 ТА ГКС АК.

${ }^{20}$ ГААК. Ф. П-1: 261.

${ }^{21}$ ГАНО. Ф. Р-11. ОП. 4a: 3.
} 
рождаемости в годы Великой Отечественной войны снижался быстрее, чем нарастал коэффициент смертности (в 1943-1945 гг. он понижался), то собственно падение рождаемости и явилось фундаментальной основой формирования отрицательных величин естественного прироста.

\section{МИГРАЦИОННЫЕ ПРОЦЕССЫ, 1941-1945 ГГ.}

Специфической формой территориальных перемещений населения в военные годы стала эвакуация населения из прифронтовых районов, оказавшихся под угрозой оккупации, а также с Дальнего Востока. К 1 декабря 1941 г. в Сибири было сосредоточено свыше 500 тыс. эвакуированных ${ }^{22}$. Перемещение в Сибирь эвакуированного населения способствовало резкой интенсификации миграций. Таблица 12 показывает, что количество населения, вселившегося в города Сибири во втором полугодии 1941 г. по отношению к довоенному полугодию 1941 г. резко выросло. В Омской области число вселившихся в города мигрантов увеличилось в 5 раз, в Алтайском и Красноярском краях - в 2,6 раза, в Новосибирской области более чем удвоилось ${ }^{23}$.

В 1942 г. эвакуация населения в восточные районы СССР была продолжена. К декабрю этого года число эвакуированных, сосредоточенных в Сибири, увеличилось до 908 тыс. человек ${ }^{24}$. Учитывая смертность и погрешности регистрации, можно утверждать, что в 1941-1942 гг. в Сибирь в порядке эвакуации прибыло свыше 1 млн человек. Из них примерно 600 тыс. человек прибыли в Сибирь во втором полугодии 1941 г. и около 400 тыс. человек - летом и осенью 1942 г.

Таблица 12. Миграционное движение городского населения Сибири в начале Великой Отечественной войны, тыс. человек*

\begin{tabular}{|c|c|c|c|}
\hline Дата & Прибыло & Выбыло & Сальдо миграций \\
\hline Первое полугодие 1941 г. & 374,5 & 277,1 & 97,4 \\
\hline Второе полугодие 1941 г. & 928,2 & 416,2 & 511,9 \\
\hline Второе полугодие в \% к первому полугодию & 247,8 & 150,2 & 525,6 \\
\hline
\end{tabular}

Источник: [Исупов 1991: 199].

Примечание: * - По территории Западной и Восточной Сибири.

В конце 1943 - начале 1944 г. в стране развернулись процессы реэвакуации, означавшие отток населения в западном направлении. До 1 июля 1944 г. численность эвакуированного населения в Сибири уменьшилась до 591,1 тыс. человек [Алексеев, Исупов 1986: 150]. К концу 1945 г. значительная часть проживавших в регионе эвакуированных вернулись на постоянное место жительства.

Основная масса населения, эвакуированного в Сибирь, на время эвакуации осела в Западной Сибири. Здесь на 1 января 1943 г., когда эвакуация была в основном завершена, было сосредоточено $88 \%$ эвакуированных, что в абсолютном выражении составляло более

\footnotetext{
22 РГАЭ. Ф. 1562. Оп. 20. Ед.хр. 306: 39 об; 45 об; 47 об.

${ }^{23}$ РГАЭ. Ф. 1562. Оп. 20. Ед.хр. 306: 1 - 1 об.; 5 - 5 об.; 51 - 51 об.; 53 - 53 об.

${ }^{24}$ РГАЭ. Ф. 1562. Оп. 20. ЕД.хр. 241: 192; РГАЭ. Ф. 1562. ОП. 20. Ед.хр. 405: 2. 
789 тыс. человек. В городских поселениях Омской области к 1 января 1943 г. разместилось 101 тыс. эвакуированных, Алтайского края - 76 тыс., в Новосибирской области - свыше 263 тыс. человек [Алексеев, Исупов 1986: 150]. В одном только Новосибирске на 1 декабря 1943 г. насчитывалось 141 тыс. эвакуированных [Алексеев, Исупов 1986: 150].

Характерной исключительно для периода войны формой организованного территориального перемещения населения был призыв людских ресурсов в рабочие колонны. Сюда направлялись лица, по тем или иным причинам непригодные к службе в Красной армии (по состоянию здоровья или по политическим мотивам: бывшие кулаки, белогвардейцы, торговцы, священнослужители, репрессированные и их близкие родственники, лица с уголовным прошлым). Учитывалась также и этническая составляющая. В рабочие колонны направлялись немцы, болгары, финны, корейцы и представители других «подозрительных» национальностей. Бойцы рабочих колонн использовались для выполнения самых тяжелых и неквалифицированных работ оборонного строительства. К марту 1942 г. в СССР было сформировано 1116 рабочих колонн. Дополнительно к этому в начале весны 1942 г. в стадии формирования пребывали 166 колонн, а бойцы 120 рабочих колонн находились в эшелонах на пути к месту постоянной дислокации. Совокупная численность личного состава рабочих колонн к 15 марта 1942 г. достигла 1264,5 тыс. бойцов [Исупов 2008: 304]. В Сибири первые рабочие колонны были сформированы в октябре 1941 г. за счет переброски трудовых ресурсов из Казахстана, а также из Новосибирской и Омской областей. К концу декабря 1941 г. в Сибирском военном округе имелись 72 рабочих колонны, в каждой из которых насчитывалось до 1000 бойцов ${ }^{25}$.

Своеобразной формой миграции была также депортация в восточные районы СССР, в том числе и в Сибирь, некоторых этнических групп. Первый крупный поток спецпереселенцев на восток страны в годы Великой Отечественной войны был организован по указу Президиума Верховного Совета СССР от 28 августа 1941 г. По данным А. А. Германа, в сентябре-октябре 1941 г. в Сибирь (в границах Красноярского и Алтайского краев, Омской и Новосибирской областей) было депортировано почти 294 тыс. немцев [Герман 1994: 358]. В 1943-1944 гг. депортации подверглись чеченцы, ингуши, карачаевцы, балкарцы, крымские татары, калмыки, болгары, греки и некоторые другие народы. Особенно большой поток спецпереселенцев, прибывших в Сибирь, составили калмыки. В январе 1944 г. В Омской области было расселено 21,2 тыс. калмыков, в Алтайском крае 20,8 тыс., в Новосибирской области - 18,3 тыс. [Полян 2001: 121]. Больше половины калмыцкого контингента, прибывшего в Омскую область, были направлены в ЯмалоНенецкий, Ханты-Мансийский национальные округа, а также в Тобольский округ [Полян 2001: 121].

В военные годы продолжались высылки так называемого «антисоветского элемента». Так, к 1 апреля 1943 г. в Новосибирской области было расселено 13,2 тыс. ссыльнопоселенцев, высланных ещё в 1941 г. из Молдавии, Прибалтики, западных областей УССР и БССР [Земсков 2005: 105]. При этом необходимо учитывать, что в Сибири уже

${ }^{25}$ ГАНО. Ф. П-4: 537. 
было расселено очень большое количество трудпоселенцев, депортированных на восток в ходе «кулацкой ссылки». По данным В.Н. Земскова, по состоянию на 1 января 1943 г. в Сибири насчитывалось 267,4 тыс. трудпоселенцев. Из них большинство было расселено в Новосибирской области (150,7 тыс. человек) и Красноярском крае (41,1 тыс. человек) [Земсков 2005: 106]. С весны 1944 г. из Западной Украины на спецпоселение стали поступать так называемые «оуновцы» - бандеровцы, мельниковцы и др. Они направлялись в отдаленные районы Красноярского края, Иркутской и Омской областей [Земсков 2005: 115]. Всего к 1 апреля 1945 г. на учете Отдела спецпоселений НКВД СССР числилось 2212,1 тыс. спецпереселенцев и ссыльнопоселенцев, из которых в Сибири было сосредоточено 629,2 тыс. человек [Земсков 2005: 115-116].

Но главным по численности и воздействию на экономические, социокультурные и демографические процессы миграционным потоком в военные годы было перемещение сельских жителей в города. Этот поток являл собой продолжение тенденций мирных лет, когда сотни тысяч жителей деревни перемещались в города для работы в промышленности, на стройках и транспорте. В 1941-1945 гг. этот миграционный поток имел некоторые особенности.

Таблица 13. Миграционное движение гражданского населения Сибири, 1942-1945, тыс. человек

\begin{tabular}{l|c|c|c}
\hline Дата & Прибыло в города & Выбыло из городов & Сальдо миграции \\
\hline 1942 & 847,6 & 596,5 & 251,1 \\
1943 & 455,1 & 321,4 & 133,7 \\
1944 & 366,5 & 377,9 & $-11,4$ \\
1945 & 391,0 & 282,4 & 108,6 \\
\hline
\end{tabular}

Источник: [Исупов 1991: 200].

Примечание: Без вочнских контингентов и депортированных.

Перемещения населения между сельскими населенными пунктами не фиксировались статистикой. Сведения о миграциях имеются только по городам, в которых информация собиралась паспортными столами милиции на основе системы пропискивыписки. Таблица 13 показывает, что после завершения эвакуации миграционная активность населения заметно понизилась. Главную роль снова стало играть миграционное направление деревня - город, но индивидуальные переселения крестьян в города были сведены к минимальным размерам. Между тем промышленные предприятия Сибири, превратившиеся в мощный арсенал Красной армии, а также транспорт и стройки требовали очень большого количества рабочей силы. Необходимо было организовать массовый приток трудовых ресурсов на предприятия тяжелой и оборонной промышленности. 13 февраля 1942 г. было принято радикальное решение о переходе к фактически принудительному принципу набора рабочей силы. В этот день увидел свет указ Президиума Верховного Совета СССР «О мобилизации на период военного времени трудоспособного городского населения для работы на производстве и строительстве» [Законодательные... 1942: 57-58]. Отныне на производство стали призывать так же, как в армию. В СССР, помимо военной, проводилась и трудовая мобилизация, причем не только городского, но и сельского населения. В ходе этих мобилизационных перемещений людей (включая сюда 
призыв мужчин в армию и рабочие колонны) сибирская деревня отдала все без остатка людские ресурсы на нужды обороны страны.

\section{ЗАКЛЮЧЕНИЕ}

В годы Второй мировой войны население Западной Сибири испытало на себе воздействие мощных процессов, обусловивших радикальную трансформацию демографической системы.

Резкие изменения численности населения были вызваны мобилизацией населения в армию и активно развернувшимися в годы войны миграционными процессами, прежде всего эвакуацией. В результате этих воздействий резко сократилась численность сельского населения, но количество горожан за счет притока мигрантов возросло. В результате сочетания этих факторов резко вырос удельный вес городского населения региона, произошла его квазиурбанизация. Кардинально изменился половозрастной состав населения, что вместе с социально-экономическими факторами привело к изменению характера воспроизводственных процессов.

Направление изменений основных воспроизводственных процессов обозначилось еще до войны - в 1939 - первой половине 1941 г. С началом Великой Отечественной войны развитие этих тенденций значительно ускорилось - сокращение рождаемости и рост смертности всегда были естественными спутниками войн.

Рождаемость в годы войны значительно снизилась. Основными факторами, обусловившими снижение рождаемости, являлись суровые жизненные условия военных лет, а также возникший дефицит мужчин. Снижение рождаемости привело к отрицательным значениям естественного прироста в 1942-1944 гг. Тем не менее с ослаблением действия внешних факторов ситуация с рождаемостью и брачностью начала возвращаться к прежнему виду, что свидетельствует о стойкости традиционного типа воспроизводственных отношений в обществе этого периода.

Смертность же, после естественного в военных условиях повышения, с 1943 г. резко падает, снизившись к концу войны более чем в 2 раза относительно предвоенного периода. Причиной снижения смертности служил переход от экзогенного к эндогенному типу смертности. Инфекционные (острозаразные, желудочно-кишечные) болезни утратили свою главенствующую роль как причина гибели людей. Основным фактором, обусловившим такое развитие событий, являлась деятельность советского здравоохранения, что, несомненно, является его крупным достижением.

Миграции в годы Великой Отечественной войны приняли весьма специфический характер. В мирные годы преобладали миграции, вызванные главным образом экономическими причинами. В военный период основными детерминантами пространственных перемещений людей стали военно-политические факторы. Они не только придавали миграциям аномальный характер, но изменили саму суть территориальных перемещений населения, их внутреннее содержание. Эти миграции было 
бы правильно обозначить как экстраординарные. Государственный контроль над территориальными перемещениями людей был резко усилен.

\section{Список использованных сокращений:}

ГААК - Государственный архив Алтайского края.

ГАКО - Государственный архив Кемеровской области.

ГАНО - Государственный архив Новосибирской области.

ГАРФ - Государственный архив Российской федерации.

ГАТО - Государственный архив Томской области.

ИсАОО - Исторический архив Омской области.

РГАЭ - Российский государственный архив экономики.

ТА ГКС АК - Текущий архив государственного комитета по статистике Алтайского края.

\section{ЛИТЕРАТУРА}

Алексеев В.В., В.А. Исупов (1986). Население Сибири в годы Великой Отечественной войны. Новосибирск. 231 с.

Великая Отечественная война 1941-1945: энциклопедия (1985). М.: Советская энциклопедия. $832 \mathrm{c.}$

Вестник статистики (1965). № 1.

Во имя Победы: эвакуация гражданского населения в Западную Сибирь в документах и материалах (2005). Т.1. «Исход». Томск: Изд-во ТГПУ. 360 с.

Герман А.А. (1994). Немецкая автономия на Волге. 1918 - 1941. Часть II. Автономная республика. 1924-1941. Саратов: Изд-во Сарат. ун-та. 416 с.

Законодательные и административно-правовые акты военного времени. С 22 июня по 22 марта 1942 г. (1942). М. 144 с.

Земсков В.Н. (2005). Спецпереселенцы в СССР, 1930 - 1960. М.: Наука. 306 с.

Исупов В.А. (1991). Городское население Сибири: от катастрофы к возрождению (конец 30-х - конец 50-х гг.). Новосибирск. 291 с.

Исупов В.А. (1992). На изломе: смертность населения Сибири в начале Великой Отечественной войны // Историческая демография Сибири. Сб. научн. трудов. Новосибирск: 186-200.

Исупов В.А. (2008). Главный ресурс Победы. Людской потенциал Западной Сибири в годы Второй мировой войны (1939-1945 гг.). Новосибирск. 378 с.

Исупов В.А. (2010). Население Западной Сибири в годы Великой Отечественной войны: численность, состав, воспроизводство // Российская история. №4: 69-83.

Население России в ХХ веке: исторические очерки (2001). Т.2. 1940-1959. М.: РОССПЭН. $416 \mathrm{c}$. 
Платунов Н.И. (1976). Переселенческая политика советского государства и ее осуществление в СССР (1917 - июнь 1941 гг.). Томск: Изд-во Томск. ун-та. 283 с.

Полян П. (2001). Не по своей воле... История и география принудительных миграций в СССР. М.: Изд-во «ОГИ-Мемориал». 328 с.

Сборник законов СССР и указов Президиума Верховного Совета СССР. 1938 - 1967 (1968). Т.2. М.: Известия Советов депутатов трудящихся СССР. 896 с.

Семенов М.А. (2015). Развитие острозаразных инфекций в Западной Сибири в годы Великой Отечественной войны // Проблемы исторической демографии Сибири. Сб. науч. тр. Вып. 4 / Отв. ред. В. А. Исупов. Новосибирск: Ин-т истории СО РАН: $234-$ 253.

Урланис Б.Ц. (1960). Войны и народонаселение Европы. Людские потери вооруженных сил европейских стран в войнах XVII - XX вв. (Историко-статистическое исследование). М.: Соцэкгиз. 568 с. 


\title{
POPULATION OF WESTERN SIBERIA DURING SECOND WORLD WAR (1939-1945)*
}

\author{
VLADIMIR ISUPOV ${ }^{1 * * *}$, NADEZHDA KOROBEYNIKOVA $^{1}$, MIHAIL SEMONOV $^{1}$
}

\begin{abstract}
The article discusses the features of demographic processes in Western Siberia during the Great Patriotic War. These features consist in drastic changes in population size and structure due to the mobilization and migration typical of the war period, especially evacuation. The main determinants of the spatial movements of people during this period were military-political factors. State control over the territorial displacement of people was greatly strengthened. During the war the rural population shrank dramatically, while the number of city dwellers, due to the influx of migrants, increased. The proportion of the urban population rose, but it was a quasi-urbanization of the region. Due to changes in population structure and the general deterioration of living conditions, fertility was significantly reduced, which became the main cause of the natural decrease of the population in 1942-1944. Mortality, after increasing in the first years of the war, in 1943 began to decline, with the mortality rate in 1945 being more than twice as low as in 1941. The most important role in this reduction was played by the health care system.
\end{abstract}

Key words: population, mortality, fertility, nuptiality, Second World War, Western Siberia.

\footnotetext{
${ }^{1}$ INSTITUTE OF History OF THE SibERIAN BRANCH OF THE RAS (RUSSIA).

* THE ARTICLE IS PUBLISHED IN THE FRAMEWORK OF THE PROJECT RHSF "HUMAN POTENTIAL OF SIBERIA IN THE CONDITIONS OF SYSTEMIC TRANSFORMATION OF RUSSIAN SOCIETY IN THE TWENTIETH CENTURY", № 16-01-00412.

** CORRESPONDENCE: vladimir_2004_@mail.ru

DATE RECEIVED: FEBRUARY 2016.
}

\section{REFERENCES}

Alekseev V.V., V.A. Isupov (1986). Naselenie Sibiri v gody Velikoj Otechestvennoj vojny [Population of Siberia during the Great Patriotic War]. Novosibirsk. 231 p.

German A.A. (1994). Nemeckaya avtonomiya na Volge. 1918 - 1941. Chast' II. Avtonomnaya respublika. 1924-1941 [German autonomy at Volga. 1918-1941. Vol. II. Autonomous Republic. 1924-1941]. Saratov: Izd-vo Sarat. un-ta. 416 p.

Isupov V.A. (1991). Gorodskoe naselenie Sibiri: ot katastrofy k vozrozhdeniyu (konec 30-x konec 50-x gg.) [Urban population of the Siberia: from catastrophe to revival (from late 1930th to late 1950th)]. Novosibirsk. $291 \mathrm{p}$.

Isupov V.A. (1992). Na izlome: smertnost' naseleniya Sibiri v nachale Velikoj Otechestvennoj vojny [On the fructure: mortality of population of Siberia at the beginning of the Great Patriotic War] // Istoricheskaya demografiya Sibiri. Sb. nauchn. trudov [Historical demography of Siberia. Collection of scientific papers]. Novosibirsk: 186-200.

Isupov V.A. (2008). Glavnyj resurs Pobedy. Lyudskoy potentsial Zapadnoy Sibiri v gody Vtoroy mirovoy voyny (1939-1945 gg.) [The main source of a Victory. The human potential of Western Siberia during the Second World War (1939-1945 gg.)]. Novosibirsk. 378 p.

Isupov V.A. (2010). Naselenie Zapadnoj Sibiri v gody Velikoj Otechestvennoj vojny: chislennost', sostav, vosproizvodstvo [Population of Western Siberia during Great Patriotic war: size, structure, reproduction] // Rossijskaya istoriya [Russian history]. №4: 69-83.

Naselenie Rossii v XX veke: Istoricheskie ocherki. T.2. 1940-1959 [Population of Russia in the twentieth century. Vol.2. 1940 - 1959] (2001). Moscow: ROSSPEN. 416 p. 
Platunov N.I. (1976). Pereselencheskaya politika sovetskogo gosudarstva i ee osushhestvlenie v SSSR (1917 - iyun' 1941 gg.) [Resettlement policy in the Soviet Union and its realization (1917 - June 1941)]. Tomsk: Izd-vo Tosk. un-ta. 283 p.

Polyan P. (2001). Ne po svoej vole... Istoriya i geografiya prinuditel'nyh migracij v SSSR [Against their will: The history and geography of forced migrations in the USSR]. Moscow: Izd-vo "OGI-Memorial". 328 p.

Sbornik zakonov SSSR i ukazov Prezidiuma Verhovnogo Soveta SSSR. 1938 - 1967 [Collection of laws of rhe USSR and decrees of the Supreme Soviet of the USSR.1938-1967] (1968). T.2 [Vol.2]. Moscow: Izvestiya Sovetov deputatov trudyashchikhsya SSSR. 896 p.

Semenov M.A. (2015). Razvitie ostrozaraznyh infekcij v Zapadnoj Sibiri v gody Velikoj Otechestvennoj vojny [Extension of highly contagious infections in Western Siberia during the Great Patriotic War] // V.A. Isupov, eds. Problemy istoricheskoj demografii Sibiri. Sb. nauch. tr.Vyp.4 [Issues of historical demography of Siberia. Collection of scientific papers.Vol.4]. Novosibirsk: In-t istorii SO RAN: $234-253$.

Urlanis B.Ts. (1960). Vojny i narodonaselenie Evropy. Lyudskie poteri vooruzhennyh sil evropejskih stran v vojnah XVII - XX vv. (Istoriko-statisticheskoe issledovanie) [Wars and European population. Casualties of the armed forces of the European countries in the wars of XVII - XX centuries]. Moscow: Sotsekgiz. 568 p.

Velikaya Otechestvennaya vojna 1941-1945: enciklopediya [Great Patriotic War 1941-1945: encyclopedia] (1985). Moscow: Sovetskaya entsiklopediya. 832 p.

Vestnik statistiki [Bulletin of statistics] (1965). № 1.

Vo imya Pobedy: evakuaciya grazhdanskogo naseleniya v Zapadnuyu Sibiri v dokumentax i materialax [For the sake of Victory: evacuation of the civil population into Western Siberia through the documents] (2005). T.1 "Isxod" [Vol. 1 "Exodus"]. Tomsk: Izd-vo TGPU. 360 p.

Zakonodatel'nye i administrativno-pravovye akty voennogo vremeni. S 22 iyunya po 22 marta 1942 g. [Legislative and administrative-legal acts during the war. From 22th June 1941 till 25 march 1942.] (1942). Moscow. 144 p.

Zemskov V.N. (2005). Specpereselency v SSSR, 1930 - 1960 [Forced settlements in the Soviet Union]. Moscow: Nauka. 306 p. 